\title{
Achieving Accusation by Means of Forensic Science During the Criminal Proceedings in Romania
}

\author{
La fundamentación de la acusación por medio de las ciencias \\ forenses en el marco del procedimiento penal en Rumanía
}

\section{Delia Magherescu ${ }^{1}$}

Gorj Bar Association, Romania

delia_magherescu@yahoo.com

http://orcid.org/0000-0003-0939-1549

\begin{abstract}
Achieving the functions of criminal procedure involves elements of forensic science used to fulfill the overall purpose of criminal proceedings. The function of accusation has a set of particularities and for this reason the approach taken is a key factor in achieving justice in criminal matters both from the judicial authorities and the defendant's perspectives. The legal mechanisms provided by the justice system must ensure equilibrium between accusation, defence and judgment. The current article focuses on the particular features of the function of accusation during the criminal proceedings as well as on the manner of its being exertion by means of forensic science. In the activity of reaching the proposed objectives, an in-depth research methodology has been used consisting of qualitative methods including case study presentations and conclusions obtained through analyzing jurisprudence in case law decisions pronounced by the courts of law in criminal matters. In this context, the forensic science is one that offers entire legal means and mechanisms in order for the judicial bodies to achieve the purpose of criminal proceedings and exercising the function of accusation implicitly.
\end{abstract}

KeYwords: Crime scene investigation; Forensic examination; Function of accusation; Investigation bodies; Investigation phase; Serious crimes.

1 Doctor in Law since 2005 awarded at the State University of Moldova, Republic of Moldova. 
RESUMEN: El proceso penal incorpora elementos de las ciencias forenses, que se emplean para realizar los fines del propio procedimiento. La función de la acusación tiene una serie de particularidades, en relación con las cuales la aproximación que se realiza a esta tarea es un factor fundamental a la hora de hacer realidad los principios de justicia en el ámbito penal, desde la perspectiva tanto de las autoridades judiciales como del acusado. Los mecanismos que proporciona el sistema de justicia penal aseguran un equilibrio entre, por un lado, la acusación y la defensa y, por otro, entre la acusación y la resolución. El presente artículo se centra en ciertas características de la función de acusación en el marco de los procedimientos penales, así como en la manera en que se ejerce por medio del recurso a las ciencias forenses. Para alcanzar los objetivos propuestos, se ha empleado una metodología de investigación mixta, basada en un método cualitativo con influencia del estudio de caso y conclusiones obtenido de el análisis de la jurisprudencia en decisiones pronunciadas por los tribunales de justicia en materia penal. En este contexto, las ciencias forenses ofrecen medios y mecanismos jurídicos para que los órganos judiciales logren el objetivo del procedimiento penal, en pleno ejercicio de la función de acusación.

Palabras clave: Investigación de la escena del delito; Examen forense; Función de la acusación; Ente de investigación; Fase de investigación; Delitos graves.

SUMmaRY: Introduction. - 1. Methodology of research. - 2. Conceptual approach and the typology of crimes. -3 . Discussion on the working premises. Conclusions. Bibliography.

\section{INTRODUCTION}

The current paper presents the second of a series of three studies which together form a research project on the functions of criminal proceedings. It is focused on the function of accusation and its exercise by means of forensic science. The research conducted on the current topic highlights how both the forensic experts and the other professionals' opinions are accustomed to the scientific methods and techniques the forensic science provides them with upon carrying out criminal investigation. It is obvious that, achieving the function of accusation 
involves the prosecutor, who is entitled to use any kind of forensic examination, regulated by the Code of penal procedure, in purpose for the court of law to find the truth - res judicata pro veritate habetur - in penal cases based on scientific evidence.

The classic tripartite separation of the functions of criminal procedure of accusation, defence, and judgement has featured the criminal proceedings of Romania from centuries and is still a modern one. It is the result of dialectical harmonization of traditional judicial principles with European ones in the field of criminal proceedings, taken into account after Romania became a Member State of the European Union on the $1^{\text {st }}$ of January 2007.

Presently, following the European approach, the criminal procedure law in Romania would be inconceivable without adapting the domestic criminal procedure rules to the European ones ${ }^{2}$. From this point of view, the judicial bodies must take into consideration both the European legislation, established by the EU institutions and the provisions regulated by the European Convention on Human Rights as well as the jurisprudence stated by the European Court of Human Rights of Strasbourg ${ }^{3}$, due to Romania's status as a member of the Council of Europe.

Referring to the above stated provisions, in the domestic criminal procedure legislation some gaps have still been identified regarding the judicial institutions and principles of criminal procedure as a consequence of the European Court of Human Rights' decisions pronounced against Romania between 1990 and 2008. In essence, these refer to the right to trial within reasonable time, fair trial, presumption of innocence, and the right to defence during the criminal proceedings. The principle of solving penal cases within reasonable time, provided by the European

2 PECH, Laurent, The Rule of Law as a Guiding Principle of European Union's External Action, The Hague: T.M.C. Asser Institute, CLEER, 2012, pp. 43-47.

3 KLEINLEIN, Thomas. The procedural approach of the European Court of Human Rights: Between subsidiarity and dynamic evolution. International and Comparative Law Quarterly, v. 68, n. 1, 2019, pp. 91-110; KOSAR, David; PETROV, Jan; SIPULOVA, Katarina; SMEKAL, Hubert; VYHNANEK, Ladislav; JANOVSKY, Jozef. Domestic Judicial Treatment of European Court of Human Rights Case Law. New York: Routledge, Taylor \& Francis Group, 2020. 
Convention on Human Rights at Article 6 para 1 thereof, states that persons accused of having committed an offence are entitled to have their case heard at a fair and public trial, and within reasonable time. Considering these aspects, the Romanian legislator has reacted by seeking solutions to improve the legal framework in criminal matters ${ }^{4}$.

In both the legal and judicial context, all functions of criminal proceedings have been assigned by fundamental characteristics, one of these being structured around the function of accusation, as regulated by Article 7 of Code of penal procedure of Romania corroborated with Article 309 (1) thereof.

The current paper focuses on the function of accusation as well as on its exercising by legal means provided in the field of forensic science during the criminal proceedings ${ }^{5}$, under the principle of official character of criminal proceedings, stated at Article 7 of Code of penal procedure of Romania ${ }^{6}$, corroborated with Article 14 and Article 15 thereof. As a science of progress and technology, forensic science is useful for judicial bodies in the activity of finding truth in penal cases they are invested with in such a way for guilty defendants to be judged and convicted in accordance with their guilt, on the one hand, and the innocent to be acquitted by the court of law, on the other hand ${ }^{7}$.

4 During the last decades, the ECtHR has pronounced several decisions against Romania on this matter. JURISPRUDENTA CEDO. European Court of $\mathrm{Hu}-$ man Rights of Strasbourg. Decision of 30 September 2008: the case Draganescu v. Romania; Decision of 16 September 2008: the case Bercaru v. Romania; Decision of 29 July 2008: the case Dumitrescu v. Romania; Decision of 16 December 2008: the case Paunoiu v. Romania, 2008. Available at: https:// jurisprudentacedo.com. Accessed on July14, 2020. One of the valuable involvement of the legislator in Romania was the reform of the judiciary in penal cases was finalized with the adoption of Law no. 135 of 2010 on the new Code of penal procedure, published in the Official Journal of Romania no. 486 of 15 July 2010, into force on 1 February 2014.

5 FRASER, Jim. The application of forensic science to criminal investigation. In: NEWBURN, Tim; WILLIAMSON, Tom; WRIGHT, Alan (eds.). Handbook of criminal investigation. New York: Willan Publishing, 2007, pp. 381-402.

6 BOTIAN, Elisabeta. Drept procesual penal. Sibiu: BURG Publishing House, 2016, pp. 21-22.

7 STANCU, Emilian. Tratat de Criminalistica. Bucharest: Actami Publishing House, 2001, pp. 217-248. 
Firstly, the current paper examines the investigation bodies' priorities in the investigation stage of criminal proceedings aimed at solving penal cases based on scientific evidence. Thus, the scope of the investigation stage is concordant with the overall objective of criminal proceedings, specifically to solve penal cases on genuine and admissible evidence $^{8}$, gathered by the judicial bodies from the crime scene in such a way that criminal activity can be discovered and proven under the principle of the rapidity of proceedings ${ }^{9}$. These objectives can be achieved by scientific means and methods provided by forensic science ${ }^{10}$.

Secondly, gathering scientific evidence implies a complex activity which involves knowledge from different sciences, including forensic medicine, physics, chemistry and even mathematics. All these elements create a corpus of rules for achieving the results expected in criminal procedures.

Thirdly, the function of accusation supposes two possibilities taking into account the principle of contradictory criminal proceedings ${ }^{11}$, as stated at Article 6 para 1 of the European Convention on Human Rights. One of these refers to the legal situation in which the investigation body does not have sufficient incriminating evidence to consider that the suspect is the person who committed the offence. In such circumstances, the prosecutor must assert the suspect's innocence ${ }^{12}$. Therefore, the criminal procedure requires submitting evidence in defence.

From this perspective, forensic science clarifies certain controversial issues arising between the accusation and defence, due to the fact that the criminal procedure in Romania is not based on the

8 SKORUPKA, Jerzy. The rule of admissibility of evidence in the criminal process of continental Europe. Revista Brasileira de Direito Processual Penal, v. 7, n. 1, 2021, pp. 93-122.

9 Idem, p. 23.

10 ROUX, Claude; CRISPINO, Frank; RIBAUX, Olivier. From Forensics to Forensic Science. Current Issues in Criminal Justice, v. 24, n. 1, 2012, pp. 7-24.

11 RAOULT, Sacha. How ownership of penal history was lost: An anti synthesis of modern criminal law. Journal of Law and Conflict Resolution, v. 4, n. 2, 2012, pp. 20-26.

12 ZARAFIU, Andrei. Procedura penala. Partea generala. Partea speciala, Second ed., Bucharest: C.H. Beck, 2015, p. 20. 
accusatory principle ${ }^{13}$. For this reason, the function of accusation during the criminal proceedings in Romania features both new and traditional principles of criminal procedure.

As stated above, if the forensic examinations conclude that the accusation is not proven, then the prosecutor must waive the accusation and submit the appropriate evidence in defence. In this regard, it was highlighted that "the main purposes of the judicial bodies are those of gathering evidence, both in defence and in accusation, regarding the existence of offence as well as regarding the perpetrator" ${ }^{14}$. In this matter, doctrine has emphasized the principle of objective character of the truth the judicial bodies have to reach during the criminal proceedings ${ }^{15}$.

The second possibility concerns the standard circumstances in which the offenses are committed. The situation refers to cases in which the prosecutor has sufficient evidence to incriminate the perpetrator. In accordance with Article 309 (1) of the Code of penal procedure, corroborated with Article 7 thereof, the accusation function is exercised $e x$ officio by the prosecutor during the investigation stage in cases in which it emerges that there are evidence which conclude that a person committed the offence and there is no legal impediment regulated expressly by Article 16 (1) thereof ${ }^{16}$.

The current paper on achieving the function of accusation by means of forensic science during the criminal proceedings of Romania aims to research the common legal procedure the judicial body is invested with in the investigation stage. As the paper discusses, the forensic science is faced with several controversies arising between the defendant and the victim of offence. Furthermore, the paper explains the most relevant forensic techniques of criminal investigation used in criminal proceedings to gather scientific evidence.

13 HIGH COURT OF CASSATION AND JUSTICE of Romania. Penal Decision no. 847 of 17 October 2018. Available at: https://www.scj.ro. Accessed on March 6, 2020. MAGHERESCU, Delia. Criminalistica. Bucharest: Wolters Kluwer, 2017a, p. 36.

15 THEODORU, Grigore. Tratat de drept procesual penal, Third ed., Bucharest: Hamangiu Publishing House, 2013.

16 BOTIAN, Elisabeta. op. cit., p. 21. 
In order to achieve this purpose, a set of aims has been established in the beginning of the research study.

(i) Conducting a conceptual research on the function of accusation and the forensic means of investigation provided in relevant penal cases.

(ii) Analyzing the most relevant topics in criminal matters, both theorists and practitioners are faced with in practice related to achieving accusation by means of forensic science.

(iii) Establishing the level of forensic science's involvement in solving penal cases particularly in those crimes where special means of investigation are needed.

(iv) Developing an action plan for finding appropriate solutions on how forensic science contributes to the better organization and management of the function of accusation in the investigation stage. (v) Advancing de lege ferenda proposals the legislator should take into account in order to improve the prevailing legislation on criminal procedure.

\section{Methodology of Research}

The current research is carried out through an in-depth qualitative method, which includes jurisprudence analysis and doctrine points of view, analyzed and discussed as the general philosophy of the topic.

The main research method applies syllogism for discovering new elements from unknown parts of the investigation profile. It is also used in forensic examinations, in those penal cases investigated both in the ordinary and special procedures in which the judicial bodies agree to order them. The paper is not based on empirical research, it neither collects, nor generates data from either public or private institutions.

The results obtained, based on the research conducted on the issue of achieving accusation by means of forensic science, have in view the observations and investigations of the experts' experiences accumulated from practical activity in penal cases when carrying out 
forensic examinations in several areas, such as: homicides ${ }^{17}$, violent crimes, terrorist attacks, road accidents as well as financial crimes, including tax evasion, fraud, counterfeiting, smuggling among others ${ }^{18}$.

Last but not least, the most appropriate doctrinal references and aspects of jurisprudence are analyzed under an approach aimed at gathering the relevant viewpoints and formulating scientific directions over the sustained knowledge on achieving the function of accusation by means of forensic science. In this regard, the theories provided by doctrine are subjected to interpretation in such a manner not to divagate from the main aim of the current research, although there are several different arguments for its interpretation in one direction or another. Under the doctrine's perspective, the function of accusation, as well as its achievement during the criminal proceedings, in particular in the investigation stage, by means of forensic science is still inadequately debated in the Romanian literature. Actually, the doctrine approaches the topic from two directions dependent on scientific field of forensic examination. This means that lawyers, specialists in criminal procedure law, have adopted a clear and precise position on the elements, institutions and proceedings of the criminal procedure entirely, including the parties' rights and obligations ${ }^{19}$, while the forensic investigators are permanently focused on the forensic science activity of carrying out the forensic examinations using the principles and methods provided by this science ${ }^{20}$.

Although they appear to be independent entities, both criminal procedure law and forensic science cannot be separated due to the fact

17 MJANES, Karin L. Testing the Organized/ Disorganized Model of Sexual Homicide. Thesis, Victoria: Simon Fraser University, 2015. Available at: https:// summit.sfu.ca/item/15907. Accessed on September 24, 2020.

18 ASLAN, Deniz; EDELMANN, Robert. Demographic and offence characteristics: a comparison of sex offenders convicted of possessing indecent images of children, committing contact sex offences or both offences. The Journal of Forensic Psychiatry \& Psychology, v. 25, n. 2, 2014, pp. 121-134.

19 THEODORU, Grigore. op. cit., 2013.

20 KRUSE, Corinna. Legal storytelling in pre-trial investigations: arguing for a wider perspective on forensic evidence. New Genetics and Society. v. 31, n. 3, 2012, pp. 299-309; CARPINEAN, Ion Cristian. Rolul probelor criminalistice in aflarea adevarului. Revista de Criminologie, Criminalistica si Penologie, n. 4, 2019, pp. 83-85. 
that they create a nexus which follows the judicial activity in criminal matters being involved in reaching the aim of the criminal proceedings consisting of finding truth and solving the penal cases legally through an evidence-based result. This is the main purpose of establishing a research approach to finding results motivated scientifically to combine theoretically the two sides of the current research. On the one hand, it concerns criminal procedure law which characterizes criminal proceedings through its principles and specific institutions. On the other hand, I am referring to the forensic science whose principles and methods of investigation ${ }^{21}$ create the judicial framework of determining the function of accusation in the knowledge that if the investigation bodies do not have sufficient evidence to accuse the suspect in a penal case of having committed the offence, then they are entitled to propose and administer defending evidence.

Considering all the aspects highlighted herein, the result of the research study on achieving accusation by means of forensic science will be analyzed from the perspective emphasized by doctrine, stated by jurisprudence and considered by practitioners and gathered via the research activity conducted for this study under a theoretical and practical perspectives, including investigation bodies, lawyers, forensic experts' experience in the field.

Thus, the research results are provided through direct opinions expressed by practitioners who have argued their opinion pertinently based on their experiences of practice.

The research activity generated conclusions which provide the current topic with particular features from each category of the forensic examinations the judicial bodies use during the investigation stage. There are differences between the perspectives stated by practitioners and theorists due to their specific involvement in the field of forensic examination. Moreover, their opinions also differ in accordance with the typology of crimes or serious crimes investigated.

${ }^{21}$ COVALCIUC, Ion. New investigative techniques: Regulatory provisions and practical possibilities. Revista de Criminologie, Criminalistica si Penologie, n. 4, 2019, pp. 67-74. 


\section{Conceptual APPROACh AND the typology of CRIMES}

The issue of approaching the function of accusation and exercising its particular elements during the investigation stage has been discussed several times by the experts in criminal matters ${ }^{22}$. In this context, there is no commonly shared viewpoint on the modality of techniques and scientific methods provided by forensic science and used by the experts in the activity of investigation ${ }^{23}$.

For this reason, the idea of conducting a research on best practices in the use of forensic examination tools in the investigation phase has arisen. The activity consists of a set of conceptual issues based on working hypotheses and premises gathered from jurisprudence in criminal matters, in case law studies as well as established from a theoretical achievement.

General remarks

The first theory is featured around the professional views regarding the manner in which specific techniques, scientific methods and tactics that belong to forensic science are used to achieve the function of accusation in the investigation phase of criminal proceedings. The current hypothesis is differently analyzed by experts in forensic science according to their involvement in particular field of criminal matters. For the practitioners involved in activity of forensic investigation, the situation differs also depending on their profession, most of them being investigation bodies, lawyers, forensic experts. An insignificant part of theorists are often involved in practical activity of criminal matters.

Taking into account this criterion, the practitioners conclusions on the topic of achieving accusation by means of forensic science is approximately balanced. This means that there are no substantial differences among lawyers disposed by the criterion of their involvement in practice.

22 STOICA, Crenguta A. Cercetari privind expertizele din domeniul multimedia. Pro Lege, n. 2-3, 2019, pp. 176-189.

23 PALCU, Pavel. The Need for Diversification of Forensic Tactical Rules Applicable to Crime Scene Investigation. Journal of Legal Studies, v. 19, n. 33, 2017, pp. 150-154. 
Nevertheless, the forensic experts indicate a high degree of experience due to their level of professional experience they have gathered during the years.

For the current study, the theorists' arguments must be taken into account, because of their involvement in research activities and conclusive remarks provided, also based on practical case-law presentations. Despite their professional status, it is relevant to emphasize that some of theorists are also involved in practice, as a consequence their opinions are more accustomed to the jurisprudence aspects.

The typology of crimes

An important criterion taken into account in the matter of conducting research on achieving accusation by means of forensic science is the typology of crimes ${ }^{24}$. The most relevant kind of serious crimes are analyzed in accordance with the forensic techniques and methods used to gather scientific evidence from the crime scene regarding the crime committed, the circumstances it was committed in, as well as regarding the perpetrator. A representative list was drawn up including murder, domestic violence, robbery, road accidents with victims, explosion, detonation, burglary, economic crimes ${ }^{25}$, as presented in Table 1. Each is shown by type of forensic examination, with a short descriptive observation as well as the particular forensic examinations the judicial bodies can order to be carried out during the investigation phase ${ }^{26}$. However, the list is drafted for exemplification, not in a limited manner, due to the fact that the particular circumstances of committing crimes differ from a crime to another one. This means that other relevant forensic examinations could be ordered by the judicial bodies in accordance with the penal case's particularities.

24 D'SILVA, Karen; DUGGAN, Conor. Revisiting the overcontrolled-undercontrolled typology of violent offenders. Personality and Mental Health, n. 4, 2010, pp. 193-205.

MAGHERESCU, Delia. New Specific Techniques of Investigation for the Economic Offences. In: MOTATU, Adriana; MILITARU, Ioana Nely, (eds). Diversity and Interdisciplinarity in Business Law. Bucharest: ADJURIS International Academic Publisher, 2017b, pp. 177-192.

26 Ibidem. 
TABLE 1. Descriptive characteristics of crimes researched by typology

\begin{tabular}{|c|c|c|c|}
\hline $\begin{array}{l}\text { Crime } \\
\text { category }\end{array}$ & $\begin{array}{c}\text { Forensic } \\
\text { examinations } \\
\text { provided }\end{array}$ & $\begin{array}{c}\text { General } \\
\text { observations }\end{array}$ & $\begin{array}{l}\text { Remarks on forensic } \\
\text { examination } \\
\text { ordered }\end{array}$ \\
\hline murders & $\begin{array}{l}\text { mixed forensic } \\
\text { criminalistics } \\
\text { and medicine } \\
\text { examinations }\end{array}$ & $\begin{array}{l}\text { serious crime } \\
\text { involving specific } \\
\text { examinations } \\
\text { ordered by the } \\
\text { judicial bodies }\end{array}$ & $\begin{array}{l}\text { violent body traces } \\
\text { biological traces examination } \\
\text { genetic traces examination } \\
\text { fingerprint trace examination } \\
\text { human and goods' traces } \\
\text { routing examination } \\
\text { ballistic examination } \\
\text { material evidence } \\
\text { physical-chemical examination }\end{array}$ \\
\hline $\begin{array}{l}\text { Violent } \\
\text { crimes }\end{array}$ & $\begin{array}{l}\text { mixed forensic } \\
\text { criminalistics } \\
\text { and medicine } \\
\text { examinations }\end{array}$ & $\begin{array}{l}\text { multiple modus } \\
\text { operandi which } \\
\text { involve specific } \\
\text { examinations } \\
\text { ordered by the } \\
\text { judicial bodies }\end{array}$ & $\begin{array}{c}\text { forensic medicine examination } \\
\text { on the victim's body } \\
\text { voice and speaking } \\
\text { examination } \\
\text { drugs examination }\end{array}$ \\
\hline robbery & $\begin{array}{l}\text { mixed forensic } \\
\text { criminalistics } \\
\text { and medicine } \\
\text { examinations }\end{array}$ & $\begin{array}{l}\text { serious crime } \\
\text { involving specific } \\
\text { examinations } \\
\text { ordered by the } \\
\text { judicial bodies }\end{array}$ & $\begin{array}{c}\text { goods physical-chemical } \\
\text { examination } \\
\text { digital fingerprint examination }\end{array}$ \\
\hline $\begin{array}{c}\text { road } \\
\text { accidents } \\
\text { with victims }\end{array}$ & $\begin{array}{l}\text { mixed forensic } \\
\text { criminalistics } \\
\text { and medicine } \\
\text { examinations }\end{array}$ & $\begin{array}{l}\text { diverse results } \\
\text { that suppose } \\
\text { specific forensic } \\
\text { examinations } \\
\text { ordered by the } \\
\text { judicial bodies }\end{array}$ & $\begin{array}{c}\text { road accident forensic } \\
\text { examination } \\
\text { technical vehicle examination } \\
\text { human traces examination } \\
\text { forensic medicine examination } \\
\text { on the victim's body } \\
\text { perpetrator's alcohol } \\
\text { consumption examination }\end{array}$ \\
\hline $\begin{array}{l}\text { explosion/ } \\
\text { detonation }\end{array}$ & $\begin{array}{l}\text { simply forensic } \\
\text { examinations }\end{array}$ & $\begin{array}{c}\text { serious crime } \\
\text { usually committed } \\
\text { as terrorist } \\
\text { attacks which } \\
\text { involve specific } \\
\text { examinations }\end{array}$ & $\begin{array}{c}\text { material evidence } \\
\text { physical-chemical examination } \\
\text { arson/ detonation examination } \\
\text { imagines examination } \\
\text { graphics and technical } \\
\text { examination }\end{array}$ \\
\hline
\end{tabular}




\begin{tabular}{|c|c|c|c|}
\hline $\begin{array}{l}\text { Crime } \\
\text { category }\end{array}$ & $\begin{array}{c}\text { Forensic } \\
\text { examinations } \\
\text { provided }\end{array}$ & $\begin{array}{c}\text { General } \\
\text { observations }\end{array}$ & $\begin{array}{c}\text { Remarks on forensic } \\
\text { examination } \\
\text { ordered }\end{array}$ \\
\hline burglary & $\begin{array}{l}\text { simply forensic } \\
\text { examinations }\end{array}$ & $\begin{array}{c}\text { multiple modus } \\
\text { operandi which } \\
\text { involve specific } \\
\text { examinations } \\
\text { ordered by the } \\
\text { judicial bodies }\end{array}$ & $\begin{array}{l}\text { fingerprint examination } \\
\text { imagines examinations } \\
\text { weapon examination }\end{array}$ \\
\hline $\begin{array}{l}\text { financial } \\
\text { crimes }\end{array}$ & $\begin{array}{l}\text { simply forensic } \\
\text { examinations }\end{array}$ & $\begin{array}{l}\text { multiple modus } \\
\text { operandi which } \\
\text { involve specific } \\
\text { examinations } \\
\text { ordered }\end{array}$ & $\begin{array}{c}\text { documents graphics } \\
\text { examination } \\
\text { technical examination } \\
\text { digital examination } \\
\text { physical-chemical examination } \\
\text { goods material examination }\end{array}$ \\
\hline
\end{tabular}

Taking into account the typology of crimes, doctrine has been involved in defining the criteria for forensic examination's capacity to respond to the highly scientific character of the issues investigated. This is because, in most cases, the forensic examinations are carried out by means of empirical examination which exceeds thus the scientific criterion of appreciation. In this context, it has been emphasized that the forensic examination report contains not only the forensic examination result, but a professional expert opinion, based on expert evidence ${ }^{27}$.

Thus, the forensic examinations differ from one type of crime to another one. In practice, the same is true for serious crimes ${ }^{28}$, even committed in a transnational context. In these circumstances, the forensic expert's professional experience in investigating both crimes and serious crimes plays a leading role in solving the penal case legally

27 MACOVECIUC, Ioana; RANDO, Carolyn J.; BORRION, Herve. Forensic gait analysis and recognition: Standards of evidence admissibility. Journal of Forensic Sciences, v. 64, n. 5, 2019, pp. 1294-1303.

28 ACTIVITY REPORT. National Institute of Forensic Examinations. Ministry of Justice of Romania, 2018. Available at: https://www.inec.ro/images/Documente/RapoarteSiStudii/RA2018.pdf. October 20, 2020. 
through the pertinent, conclusive and genuine evidence gathered by the investigation bodies ${ }^{29}$.

Consequently, the practitioners' experience in penal cases becomes a key factor in the process of achieving the accusation by means of forensic examination during the criminal proceedings.

\section{DisCUSSION ON THE WORKING PREMISES}

The research activity conducted on the current topic supposes discussion on the most important issues concerning the function of accusation and its characteristics; in particular, achieving accusation by means of forensic science during the investigation stage of the criminal proceedings. The discussion is focused around the hypotheses formulated on both crimes and serious crimes. In this regard, it has been advanced no less than six working premises on the most relevant types of crimes, which occur in practice.

\section{Working premise 1: Cases of violent crimes}

The first hypothesis occurs in cases of violent serious crimes, such as homicide including domestic homicide. It is relevant that the forensic examinations have a leading role in the activity of achieving the function of accusation. Generally speaking, the forensic experts are more confident with technical examinations in cases in which both violent crimes of murder or domestic violence are committed ${ }^{30}$. The prosecutors usually order mixed forensic examinations in every one of the cases they investigate.

From this point of view, particular attention is paid on homicides ${ }^{31}$. Doctrine has opined on the forensic examinations ordered

29 MONCKTON-SMITH, Jane; ADAMS, Tony; HART, Adam; WEBB, Julia. Introducing Forensic and Criminal Investigation, Sage Publications, 2013, p. 2.

30 DOUGLAS, John E.; BURGESS, Ann W.; BURGESS, Allen G.; RESSLER, Robert K. Crime Classification Manual: A Standard System for Investigating and Classifying Violent Crime. Third ed. New Jersey: Wiley, 2013.

31 GEBERTH Vernon J. Practical homicide investigation. Tactics, procedures, and forensic techniques. Fifth ed., Boca Raton: Taylor \& Francis Group, 2015; 
by the investigation bodies that they are used in cases of homicide by shooting or poisoning, for example. In these cases, the ballistic examination of the firearms of crime $^{32}$, on the one hand, and the toxicological examination of toxic substances, on the other hand, are relevant and for this reason the investigation bodies have to take them into account in gathering evidence in the judicial procedure of exercising accusation ${ }^{33}$.

In the first situation, the means of new technology developed in the field of ballistic examination of firearms provide advanced techniques of forensic examination. In this matter, one of the most recent innovative methods is that use of bullet 3-D examining image, in purpose to enhance the experts ability "to make bullet matches through automated ballistic imaging and analysis" 34 .

For the second situation, the forensic investigators have certain indicators which provide them with information related to the victims' death, which was or was not produced by violence. The presence of violent signs on the victims' body is one of these indicators which must be corroborated with the results of toxicological examination, as well as the medico-legal examination of autopsy.

In practice, the investigation body orders medico-legal examinations in purpose to establish if the victim's death is the result of the defendant's direct and immediate criminal act. In this case, the medico-legal examination report has established that the victim's death has been provoked by the violent acts committed by defendant over the

SANTORO, Paola; LA RUSSA, Raffaele; BESI, Livia; VOLONNINO, Gianpietro; DELL'AQUILA, Massimiliano; DE MATTIES, Alessandra; MAIESE, Aniello, The forensic approach to plastic bag suffocation: Case report and review of the literature, Medico-Legal Journal, v. 87, n. 4, 2019, pp. 214-220.

32 BRAGA, Anthony A.; PIERCE, Glenn L. Reconsidering the ballistic imaging of crime bullets in gun law enforcement operations. Forensic Science Policy \& Management: An International Journal, v. 2, n. 3, 2011, pp. 105-117; THOMPSON, Robert M. Firearm Identification in the Forensic Science Laboratory. Arlington, VA: National District Attorneys Association, 2010, pp. 11-13.

33 MONCKTON-SMITH, Jane; ADAMS, Tony; HART, Adam; WEBB, Julia, op. cit., p. 2.

34 BRAGA, Anthony A.; PIERCE, Glenn L., op. cit., pp. 105-117. 
victim's body. It is considered so because of many lesions existed on the victim's body, which conducted to death ${ }^{35}$.

The criminal investigation of serious crimes of homicide states that the ballistic forensic examination provides important information regarding the gun used by perpetrator, the type of gun, the gun traces on both the victim's body and in the environmental area, and the bullet traces as well. However, there are situations in which the perpetrator uses cartridges manufactured from plastic, which are destroyed simultaneously with the burning gunpowder ${ }^{36}$. In these cases, the forensic experts activity of forensic examination is complex and complicated, because of the material evidence destroyed at the time of committing criminal act - dolus ex re.

Other forms of violent crimes are also investigated by the prosecutor through conducting at least one forensic examination during the investigation stage. The DNA forensic examination is a significant part of the forensic experts' activity ${ }^{37}$. It is actually carried out by the forensic medicine experts in close cooperation with the forensic investigators, whose results depend on the DNA examination result established previously ${ }^{38}$.

Doctrine has emphasized that the DNA examination is "the result of a biological examination, which states data regarding the individuals' genetic information (...). Through this genetic evidence, it has been demonstrated scientifically that a person belongs to a unique DNA and there are no two individuals having the same DNA profile" 39 . For this reason, the bio-forensic examination ordered in purpose to

35 CRIMINAL DECISION no. 428/RC of 28 November 2018 of the High Court of Cassation and Justice of Romania. Available at: http://www.scj.ro. Accessed on July 16, 2020.

36 STANCU, Emilian. op. cit., p. 256.

37 WALTKE, Heather; LAPORTE, Gerald; WEISS, Danielle; SCHWARTING, Dawn; NGUYEN, Minh; SCOTT, Frances. Sexual Assault Cases: Exploring the Importance of Non-DNA Forensic Evidence. NIJ Journal, n. 279, 2018, pp. 3547. Available at: https://www.ojp.gov/pdffiles1/nij/250696.pdf. Accessed on May 8, 2021. STANCU, Emilian. op. cit., 2001.

MAGHERESCU, Delia. Criminalistica. Bucharest: Wolters Kluwer, 2017a, p. 202. 
establish the DNA profile is a very important activity, carried out by the forensic experts due to the fact that it provides them with the exact data to identify the perpetrator. From a procedural point of view, they are absolute evidence administered during the criminal proceedings the investigation bodies should be based on in order to achieve the accusation in penal case.

From a practical point of view, it has been stated that a wrong decision could be pronounced in cases of homicide, in which the defendants are convicted in the absence of a DNA forensic examination ${ }^{40}$. Such errors occurred in practice ${ }^{41}$ and, for this reason, they must be avoided entirely ${ }^{42}$. In this matter, a penal case can be considered as providing the judicial truth $^{43}$ regarding the crime and the perpetrator, imposing erga omnes effects. Therefore, the judicial bodies are not entitled to carry out new investigation activities regarding the other persons, such obligation coming into effect once the decision of acquittal was finally ruled in the penal case. In fact, the case decision was pronounced by the court of law, while the definitive decision of acquittal coincides with the moment in which both the forensic experts and the investigation bodies have had access to the genetic DNA examination ${ }^{44}$. It is considered that the scientific analysis is carried out through the biological samples drawn from suspected persons, and crime victims. Using the comparative methods, the forensic experts

40 SCHROEDER, David A.; ELINK-SCHUURMAN-LAURA, Kristin. The impact of forensic evidence on arrest and prosecution. National Institute of Justice. Boston: University of New Haven, 2017, pp. 1-92. Available at: https://www. ojp.gov/pdffiles1/nij/grants/250721.pdf. Accessed on May 8, 2021.

41 CRIMINAL DECISION no. 2801 of 12 September 2012 of the High Court of Cassation and Justice of Romania. Available at: http://www.scj.ro. Accessed on July 16, 2020.

42 SANGERO, Boaz; HALPERT, Mordechai. Why a conviction should not be based on a single piece of evidence: A proposal for reform, Jurimetrics, v. 48, n. 1, 2007, pp. 43-94. Available at: https://www.jstor.org/stable/25767388?seq=1. Accessed on May 8, 2021.

43 ROBERTSON, James. Forensic science, an enabler or dis-enabler for criminal investigation? Australian Journal of Forensic Sciences, v. 44, n. 1, 2012, pp. 83-91.

44 CRIMINAL DECISION no. 2137 of 3 April 2006 of the High Court of Cassation and Justice of Romania. Available at: http://www.scj.ro. Accessed on July 16, 2020. 
can obtain evidence which can conduct to finding truth and solving penal case under conclusive, pertinent and genuine evidence.

\section{Working premise 2: Cases of terrorist attack}

Another issue focuses on the cases of serious crimes of terrorist attacks. The forensic experts have determined that in cases of explosion and detonation the most significant scientific evidence is that based on the forensic examination by means of chemical techniques. In cases of crimes committed through explosion and detonation "the diverse features of these technical phenomena as well as their modus operandi or even the varied evolution make from the offenses committed by detonation as being serious ones. (...) The detonation evolution and its consequences, which destroy the evidence so necessary for the entire penal investigation through the burning process, make difficult both the judicial bodies and the forensic experts' activity. Moreover, the explosive materials used by the perpetrators in committing the criminal acts are destroyed through the same burning process" ${ }^{45}$. In these situations, the forensic experts are looking for finding evidence, such as cinders resulted from the burning materials found in the proximity area and carbonized elements providing information on the burnt fragments. At the same time, the fragments of device, which released the explosion, can offer information to the forensic experts on the criminal modus operandi used by the perpetrator in committing crime ${ }^{46}$.

Another category of crimes discussed is related to those committed by arson followed by explosion. It is frequently used by perpetrators in committing terrorist attacks. The forensic examination of prohibited substances used in committing serious crimes, usually at the international level, are relevant for the judicial bodies in the judicial activity of solving penal cases ${ }^{47}$.

45 MAGHERESCU, Delia. New Specific Techniques of Investigation for the Economic Offences. In: MOTATU, Adriana; MILITARU, Ioana Nely, (eds). Diversity and Interdisciplinarity in Business Law. Bucharest: ADJURIS International Academic Publisher, 2017b, pp. 177-192.

46 Ibidem.

47 WOODMAN, Peter A.; SPIRANOVIC, Caroline; JULIAN, Roberta; BALLANTYNE, Kaye N.; KELTY, Sally F. The impact of chemical trace evidence on 
The practitioners have related the practice regarding the individual character of the forensic examination and its connection to the other evidence gathered by the investigation bodies from the crime scene. The procedure indicates that forensic examination leads exclusively to solving the penal cases of serious crimes, such as those committed through explosion and detonation. Two kinds of forensic examinations are carried out in these cases.

The first is the physical-chemical examinations ${ }^{48}$ which refer to the optic microscopic technique, electronic scanning microscopic technique, the chromatography in both the gaseous and liquid phases ${ }^{49}$. In practice, it has been stated that "the hi-tech devices as well as the use of innovative techniques for the above mentioned areas help the forensic science, which has made huge steps in the last period of time"50.

The second kind is characterized by the technical examinations. None of these have a pre-established judicial value: They are corroborated with the other evidence gathered by the investigation bodies ${ }^{51}$. This is the main principle applicable in criminal matters, whose value is designed by the elements of scientific analysis. The judge is the only one judicial authority able to corroborate evidence each other at the deliberative stage of penal trial, in such a manner to pronounce the judicial decision legally and substantially, at the end of criminal proceedings.

Working premise 3: Cases of transnational organized crimes

Regarding the transnational organized crimes, the forensic investigators often provide their opinions on the forensic examinations conducted by the investigation bodies in order to achieve the accusation by scientific evidence. They have deemed that the forensic examinations

justice outcomes: Exploring the additive value of forensic science disciplines. Forensic Science International, v. 307, 2020, pp. 110-121.

GEHL, Rod; PLECAS, Darryl. Introduction to Criminal Investigation: Processes, Practices and Thinking. New Westminster, BC: Justice Institute of British Columbia. 2016, p. 148. Available at: https://pressbooks.bccampus.ca/criminalinvestigation. Accessed on April 4, 2020.

49 MAGHERESCU, Delia. Criminalistica. Bucharest: Wolters Kluwer, 2017a.

50 Ibidem.

51 STANCU, Emilian. op. cit., 2001. 
on counterfeiting goods of any kind are usually conducted by the forensic experts during the investigation phase.

Another issue was the transnational organized crime in which the forensic examination is conducted in a particular manner due to the fact that the investigation activity in these cases is a specialised one ${ }^{52}$. Investigators has faced the challenge regarding the forensic examination undertaken by the judicial bodies in cases, such as those related to counterfeiting goods $s^{53}$. It is well-known that the activity of counterfeiting supposes firstly the action of falsification, consisting particularly in falsifying materials part of products that the perpetrator plans to trade. The procedure of forensic investigation in such cases uses the scientific methods of analyzing constitutive elements, provided by the judicial chemistry - a new concept, welcomed by the scientific techniques of forensic investigation of textile, plastic materials as well as any other substances ${ }^{54}$.

Another kind of serious crime examined by the forensic examination is trafficking in drugs, most of the time committed in a transnational manner. The diversity of drugs as well as the routes covered by traffickers in a transnational way implies several forensic examinations. For this reason, it could be stated that the investigation activity is a complex one. The same complexity applies to the forensic examination in cases of trafficking in arms and trafficking in persons ${ }^{55}$. In practice, the court

52 DOUGLAS, John E.; BURGESS, Ann W.; BURGESS, Allen G.; RESSLER, Robert K. Crime Classification Manual: A Standard System for Investigating and Classifying Violent Crime, op. cit., 2013.

DUMBA, Dumitru. Consideratiuni in legatura cu dispunerea prin ordonanta de catre procurorul care efectueaza urmarirea penala a expertizelor care au ca obiect stabilirea valorii in vama a marfurilor. Dreptul, n. 9, 2010, pp. 167-177.

54 MAGHERESCU, Delia. New Specific Techniques of Investigation for the Economic Offences. In: MOTATU, Adriana; MILITARU, Ioana Nely, (eds). Diversity and Interdisciplinarity in Business Law. Bucharest: ADJURIS International Academic Publisher, 2017b, pp. 190.

55 UNITED NATIONS OFFICE ON DRUGS AND CRIME. Anti-human trafficking manual for criminal justice practitioners: Crime scene and physical evidence examinations in trafficking in persons investigations, Vienna, 2009, pp. 1-32. Available at: https://www.unodc.org/documents/human-trafficking/TIP module7_Ebook.pdf. Accessed on October13, 2020; CRIMINAL DECISION no. 350 of 28 June 2019 of the High Court of Cassation and Justice of Romania. Available at: http://www.scj.ro. Accessed on July 16, 2020; MASSEY, 
of law admitted the criminal accusation submitted by the prosecutor ${ }^{56}$ and condemned the defendant for committing the qualified transnational trafficking in arms ${ }^{57}$.

Working premise 4: Cases of forged documents

Another point of view is focused on the idea of the forensic examination of writing in cases of document forgery ${ }^{58}$. Indeed, the cases of counterfeiting documents are often met in practice. The investigation bodies are frequently invested with cases in which ordering forensic examinations of writing for the forged documents are necessary in purpose to gather evidence by means of scientific forensic methods.

De facto, the forensic examination of documents involves several activities. They refer mainly to the following category:

- the forensic investigation of handwriting;

- the forensic technical examination of documents;

- the forensic investigation of official documents.

The offenses of counterfeiting documents are incriminated in different ways by the legislation in criminal matters into force. The differences depend on the modus operandi preferred by the perpetrator. In this matter, the legislator has protected both the official and private documents, and the courts of law are called to void the forged document ${ }^{59}$

Simon; RANKIN, Glynn. Exploiting people for profit. Trafficking in human beings. London: Palgrave Macmillan, 2020, pp. 53-74.

CRIMINAL DECISION no. 385/RC of 31 October 2018 of the High Court of Cassation and Justice of Romania. Available at: http://www.scj.ro. Accessed on July 16, 2020.

57 According to Article 271 of Law no. 86 of 2006 on the Custom Code of Romania, corroborated with Article $75(2 / \mathrm{b})$ and Article 76 (1) of the Penal Code of Romania.

58 MONCKTON-SMITH, Jane; ADAMS, Tony; HART, Adam; WEBB, Julia, op. cit., p. 2; TOUZEAU, Nadine. Transposition of modus operandi from the real to the virtual using several signatures: Case of "the drowned of the Garonne" serial crimes in France. Forensic Science and Criminology, v. 3, n. 1, 2018, pp. 1-2.

59 PRELIMINARY DECISION no. 113 of 22 February 2019 of the High Court of Cassation and Justice of Romania. Available at: https://www.scj.ro. Accessed on April 15, 2020. 
in purpose to re-establish the initial legal status, as well as the general social order provided by the law on official and private documents.

The forensic examinations of the perpetrators' papillary traces in several cases have a significant relevance in practice. The fingerprint identification is so common in penal cases committed by the perpetrators and related to the forged documents once they are distributed on the public market. The High Court of Cassation and Justice of Romania ${ }^{60}$ has stated that "the information provided by the European arrest warrant are sufficient for the court of law to take into account the circumstances disposed by the legislation in criminal matters. Thus, it is stated that the investigation stage in the current case is an incipient one, and the Belgian authorities' request is based on the identification of papillary fingerprints of the requested person, existed on the counterfeiting banknotes handle over the victim, aspect which necessitates explanations in order to establish the implication of each involved person".

Regarding the forensic fingerprint examination carried out in this case, which has concluded that the fingerprint traces belong to the suspected person, the court of law has stated that "referring to the suspected person's declaration that he has not ever been in Belgium during 2016-2019, the procedure of drawing papillary traces of the suspected person from the counterfeiting banknotes necessitates elucidations on how they have been identified on these banknotes, as well as to establish the limits of criminal activity imposed by the judicial authorities of Belgium" ${ }^{61}$.

\section{Working premise 5: Cases of road accidents}

A particular type of crime investigated by means of forensic science is the road accident in which at least one victim is involved. Crimes of road accidents are so common for the judicial investigation bodies, which will certainly require a road accident forensic examination regarding the vehicles' dynamics in cases of road accidents in order to establish the circumstances the offense was committed in. Due to the

\footnotetext{
60 CRIMINAL DECISION no. 542 of 30 October 2019 of the High Court of Cassation and Justice of Romania. Available at: http://www.scj.ro. Accessed on July 16, 2020.

61 Ibidem.
} 
modus operandi, the road accident forensic examination in these cases supposes several operations, techniques and methods of discovering traces, sampling and examining them in order to provide relevant information on committing offense. The most frequent ordered forensic examinations are those related to:

- establishing dynamics of road accident;

- establishing direction of vehicle's circulation;

- establishing time of impending state of danger;

- establishing the speed of vehicle's circulation;

- establishing the place of impact;

- establishing the degree of auto tires and rims' tear;

- evaluating points of impact and roadway conditions;

- establishing possibility of avoiding road accident.

All these objectives should be followed by the technical examination of vehicle, which is often limited to technical aspects on carrying out forensic examinations of the pieces of the vehicle's safety system $^{62}$, in purpose to state if they have had a particular involvement in deficient working of vehicle and subsequently caused the road accident. In this case, there is no attention paid to analysing dynamics or the circumstances the roar accident was committed in.

For this reason, it could be pointed out that, in cases of road accidents, the physical-chemical examinations will be ordered by the judicial bodies with an aim to find out the circumstances of committing offense.

In cases of road accidents, the main principle of crime scene investigation requires that the forensic investigators should evaluate immediately the evidence in order for them to establish as fair as possible the way of producing offense. The principle is also accustomed to the function of preservation of evidence on the crime scene, especially those which might be destroyed by weather conditions, such as wind, rain a.s.o. or even contaminated by the assistant wirnesses.

62 ITAI. Good Practice in Forensic Road Collision Investigation. A guide for Practitioners. NPCC: South Cerney, 2019, pp. 1-60. Available at: https:// www.itai.org/download/Good-Practice-in-Forensic-Road-Collision-Investigation-V2A.pdf. Accessed on August 12, 2020. 
The evidence sampled from the crime scene are usually examined chemically. They consist in elements, such as glass elements, textile materials, plastic, metal, diesel oil, petrol fragments, or even victim's clothes pieces and biological samples. In cases of suspects who left the crime scene until its investigation, any of their clothes pieces are useful as well. Every substance and element should not be replaced or moved next to the victims' body in purpose to avoid the interference each other, having repercussion on the chemical testing.

The forensic examinations ordered depend of the typology of offenses whose particularities present interest for the penal case entirely. The medico-legal examination is carried out in cases of road accidents with dead victims. In such cases, the forensic legal expert should investigate the crime scene before the time of removing body. In practice, the procedure varies, but generally speaking the forensic legal expert should accompany the forensic investigator to the crime scene in a mixed investigation team.

Last but not least, the investigation procedure carried out on the crime scene of road accident involves the activity of gathering witnesses' statements in close area of the offence committed and in a shortest time period after producing road accident. Although they do not provide absolute evidence, the eye-witnesses are useful in the beginning of forensic investigation. They will then be appointed for the hearing procedure, which will be conducted under the principles stated for the forensic tactics of hearing people in criminal proceedings.

Nevertheless, there are gaps in practice in the matter of examining samples gathered from the crime scene. In this matter, the judicial bodies must take into account the proposals advanced by the forensic experts on the way in which the gaps can be solved by finding appropriate solutions including legislative ones. Moreover, the legislator could take practical issues into account in seeking to improve the legislation in criminal matters on exercising the function of accusation by means of forensic science.

Working premise 6: Cases of financial crimes

The forensic experts have opined that the national and transnational financial crimes are the subject to forensic examinations 
in cases in which tax evasion, fraud, counterfeiting, and smuggling are committed ${ }^{63}$. The complex nature of transnational crimes creates premises for a complex forensic examination as well. Thus, doctrine has pointed out that "the judicial bodies need some specific knowledge from different areas of sciences than the legal one. In this manner, in order for them to administrate evidence for solving legally the penal law conflict, they need to utilize certain special means of evidence. The forensic examinations, with the data and information provided, belong to this category and help the instance to pronounce the legal and justified decision in a case" ${ }^{64}$.

In the matter of achieving accusation, the forensic science states what kind of forensic examinations are relevant in the cases of serious crimes, also connected to the corruption ones which bring together illegal activity in the field of business and law enforcement. In practice, it has been stated that, in cases of trafficking in influence committed by civil servants in their professional activity of exercising the legal duties in a public function, as regulated by Article 291 of the Penal Code of Romania, the judicial bodies will order the voice and speaking forensic examination over the conversations recorded in the surrounding environment and discussed between defendant and informant ${ }^{65}$.

\section{Conclusions}

Under the last legislative amendment and entrance into force of the new Code of penal procedure in Romania on the $1^{\text {st }}$ of February 2014, the legal framework in criminal matters has been changed substantially. Achieving accusation by means of forensic science is a real challenge for

63 MAGHERESCU, Delia. New Specific Techniques of Investigation for the Economic Offences. In: MOTATU, Adriana; MILITARU, Ioana Nely, (eds). Diversity and Interdisciplinarity in Business Law. Bucharest: ADJURIS International Academic Publisher, 2017b, pp. 177-192.

${ }^{64}$ Idem, p. 187.

65 CRIMINAL DECISION no. 277/A of 29 October 2018 of the High Court of Cassation and Justice of Romania. Available at: http://www.scj.ro. Accessed on July 16, 2020. 
the investigation bodies who seek appropriate solutions for finding truth in the penal cases ${ }^{66}$ they are invested with, as well as for solving them through conclusive, pertinent and genuine evidence, as scientific ones, gathered by means of new technologies provided by the forensic science.

The judicial means of gathering evidence are diverse and consist of methods and means regulated by the Code of penal procedure being obtained during the investigation phase ${ }^{67}$, while the other procedural activities are conducted including the judicial search, gathering goods and documents, also achieved by means of forensic science. Using the means of forensic science during the investigation phase is always directed in the penal cases of both serious crimes and common offenses.

In this judicial architecture, the judicial bodies are bound to collect judicial samples drawn from the crime scene and surrendering them to the forensic experts ${ }^{68}$ in order to obtain scientific evidence.

As de lege ferenda proposal, the methodology of gathering forensic evidence must be standardized for each kind of sample drawn. Based on this standardization, the judicial bodies would be obliged to respect the integrated methodology of drawing experimental forensic evidence. Consequently, they would be directed not to neglect aspects that are useful for the forensic examination procedure. Moreover, the procedure would enhance the judicial bodies' active role, on the one hand, and can advance the idea of their suitability with concrete data of the penal case investigated, on the other hand. This means that a more efficient cooperation between the investigation body and the forensic expert

66 ZARAFIU, Andrei. Implications of the new legislation on the fundamental principles of the criminal trial. Challenges of the Knowledge Society. Bucharest: "Nicolae Titulescu" University Publishing House, 2015, pp. 145-155. Available at: https://www.proquest.com/openview/69cb9471aa57f00f829a7d6cf5465638/1?pq-origsite=gscholar\&cbl=2036059. Accessed on May 13, 2021.

67 KAIJA, S. Issues in separation of criminal procedural functions. Society. Health. Welfare. 2016, v. 40, 2018, pp. 1-10.

68 AITKEN, Colin; ROBERTS, Paul; JACKSON, Graham. Fundamentals of Probability and Statistical Evidence in Criminal Proceedings. Guidance for Judges, Lawyers, Forensic Scientists and Expert Witnesses. Royal Statistical Society, v. 121, 2010, pp. 18-22. Available at: https://www.maths.ed.ac.uk/ cgga/ Guide-1-WEB.pdf. Accessed on May 10, 2021. 
is necessary in the context of approaching the particularities of the investigated case $\mathrm{e}^{69}$ and, in this matter, the standardized procedure will guide their activities ${ }^{70}$.

\section{BIBLIOGRAPHY}

ACTIVITY REPORT. National Institute of Forensic Examinations. Ministry of Justice of Romania, 2018. Available at: https://www.inec.ro/images/Documente/ RapoarteSiStudii/RA2018.pdf. October 20, 2020.

AITKEN, Colin; ROBERTS, Paul; JACKSON, Graham. Fundamentals of Probability and Statistical Evidence in Criminal Proceedings. Guidance for Judges, Lawyers, Forensic Scientists and Expert Witnesses. Royal Statistical Society, v. 121, pp. 18-22, 2010. Available at: http://eprints.nottingham.ac.uk/1859/1/Aitken,_Roberts_\&_Jackson,_Fundamentals_of_Probability_and_Statistical_Evidence_(2010). pdf. Accessed on February 25, 2020.

ASLAN, Deniz; EDELMANN, Robert. Demographic and offence characteristics: a comparison of sex offenders convicted of possessing indecent images of children, committing contact sex offences or both offences. The Journal of Forensic Psychiatry \& Psychology, v. 25, n. 2, pp. 121-134, 2014. https://doi.org/10.1080/ 14789949.2014.884618

BOTIAN, Elisabeta. Drept procesual penal. Sibiu: BURG Publishing House, 2016.

BRAGA, Anthony A.; PIERCE, Glenn L. Reconsidering the ballistic imaging of crime bullets in gun law enforcement operations. Forensic Science Policy \& Management: An International Journal, v. 2, n. 3, pp. 105-117, 2011. https://doi.org/ 10.1080/19409044.2011.613444

CARPINEAN, Ion Cristian. Rolul probelor criminalistice in aflarea adevarului. Revista de Criminologie, Criminalistica si Penologie, n. 4, pp. 83-85, 2019.

COVALCIUC, Ion. New investigative techniques: Regulatory provisions and practical possibilities. Revista de Criminologie, Criminalistica si Penologie, n. 4, pp. 67-74, 2019.

69 HORSWELL, John. The Practice of Crime Scene Investigation. London - New York: Taylor\&Francis, 2004.

70 HOWES, Loene $\mathrm{M}$. The communication of forensic science in the criminal justice system: A review of theory and proposed directions for research. Science and Justice, v. 55, n. 2, 2015, pp. 145-154. 
CRIMINAL DECISION no. 2801 of 12 September 2012 of the High Court of Cassation and Justice of Romania. Available at: http://www.scj.ro. Accessed on July 16, 2020.

CRIMINAL DECISION no. 2137 of 3 April 2006 of the High Court of Cassation and Justice of Romania. Available at: http://www.scj.ro. Accessed on July 16, 2020.

CRIMINAL DECISION no. 277/A of 29 October 2018 of the High Court of Cassation and Justice of Romania. Available at: http://www.scj.ro. Accessed on July 16, 2020.

CRIMINAL DECISION no. 542 of 30 October 2019 of the High Court of Cassation and Justice of Romania. Available at: http://www.scj.ro. Accessed on July 16, 2020.

CRIMINAL DECISION no. 350 of 28 June 2019 of the High Court of Cassation and Justice of Romania. Available at: http://www.scj.ro. Accessed on July 16, 2020.

CRIMINAL DECISION no. 385/RC of 31 October 2018 of the High Court of Cassation and Justice of Romania. Available at: http://www.scj.ro. Accessed on July 16, 2020.

CRIMINAL DECISION no. 428/RC of 28 November 2018 of the High Court of Cassation and Justice of Romania. Available at: http://www.scj.ro. Accessed on July 16, 2020.

DOUGLAS, John E.; BURGESS, Ann W.; BURGESS, Allen G.; RESSLER, Robert K. Crime Classification Manual: A Standard System for Investigating and Classifying Violent Crime.Third ed. New Jersey: Wiley, 2013.

D'SILVA, Karen; DUGGAN, Conor. Revisiting the overcontrolled-undercontrolled typology of violent offenders. Personality and Mental Health, n. 4, pp. 193-205, 2010. https://doi.org/10.1002/pmh.130

DUMBA, Dumitru. Consideratiuni in legatura cu dispunerea prin ordonanta de catre procurorul care efectueaza urmarirea penala a expertizelor care au ca obiect stabilirea valorii in vama a marfurilor. Dreptul, n. 9, pp. 167-177, 2010.

FRASER, Jim. The application of forensic science to criminal investigation. In: NEWBURN, Tim; WILLIAMSON, Tom; WRIGHT, Alan (eds.). Handbook of criminal investigation. New York: Willan Publishing, 2007.

GEBERTH Vernon J. Practical homicide investigation. Tactics, procedures, and forensic techniques. Fifth ed., Boca Raton: Taylor \& Francis Group, 2015.

GEHL, Rod; PLECAS, Darryl. Introduction to Criminal Investigation: Processes, Practices and Thinking. New Westminster, BC: Justice Institute of British Columbia. 
2016. Available at: https://pressbooks.bccampus.ca/criminalinvestigation. Accessed on April 4, 2020.

HIGH COURT OF CASSATION AND JUSTICE of Romania. Penal Decision no. 847 of 17 October 2018. Available at: https://www.scj.ro. Accessed on March 6, 2020.

HORSWELL, John. The Practice of Crime Scene Investigation. London - New York: Taylor\&Francis, 2004.

HOWES, Loene M. The communication of forensic science in the criminal justice system: A review of theory and proposed directions for research. Science and Justice, v. 55, n. 2, pp. 145-154, 2015. https://doi.org/10.1016/j.scijus.2014.11.002

ITAI. Good Practice in Forensic Road Collision Investigation. A guide for Practitioners. NPCC: South Cerney, 2019. Available at: https://www.itai.org/download/ Good-Practice-in-Forensic-Road-Collision-Investigation-V2A.pdf. Accessed on August 12, 2020.

JURISPRUDENTA CEDO. European Court of Human Rights of Strasbourg, 2008. Available at: https://jurisprudentacedo.com. Accessed on July14, 2020.

KAIJA, S. Issues in separation of criminal procedural functions. Society. Health. Welfare, v. 40, 2018, pp. 1-10. https://doi.org/10.1051/shsconf/20184001010

KLEINLEIN, Thomas. The procedural approach of the European Court of Human Rights: Between subsidiarity and dynamic evolution. International and Comparative Law Quarterly, v. 68, n. 1, pp. 91-110, 2019. https://doi.org/10.1017/ S0020589318000416

KOSAR, David; PETROV, Jan; SIPULOVA, Katarina; SMEKAL, Hubert; VYHNANEK, Ladislav; JANOVSKY, Jozef. Domestic Judicial Treatment of European Court of Human Rights Case Law. New York: Routledge, Taylor \& Francis Group, 2020.

KRUSE, Corinna. Legal storytelling in pre-trial investigations: arguing for a wider perspective on forensic evidence. New Genetics and Society. v. 31, n. 3, pp. 299309, 2012. https://doi.org/10.1080/14636778.2012.687084

LAW no. 135 of 2010 on the new Code of Criminal procedure, published in the Official Journal of Romania no. 486 of 15 July 2010, into force on 1 February 2014.

MACOVECIUC, Ioana; RANDO, Carolyn J.; BORRION, Herve. Forensic gait analysis and recognition: Standards of evidence admissibility. Journal of Forensic Sciences, v. 64, n. 5, pp. 1294-1303, 2019. https://doi.org/10.1111/1556-4029.14036

MAGHERESCU, Delia. Criminalistica. Bucharest: Wolters Kluwer, 2017a. 
MAGHERESCU, Delia. New Specific Techniques of Investigation for the Economic Offences. In: MOTATU, Adriana; MILITARU, Ioana Nely, (eds). Diversity and Interdisciplinarity in Business Law. Bucharest: ADJURIS International Academic Publisher, 2017b. Available at: http://www.adjuris.ro/reviste/daib/Diversity\%20 and\%20Interdisciplinarity\%20\%20\%20\%20\%20\%20\%20in\%20Business\%20Law. pdf. Accessed on September 21, 2020.

MASSEY, Simon; RANKIN, Glynn. Exploiting people for profit. Trafficking in human beings. London: Palgrave Macmillan, 2020.

MJANES, Karin L. Testing the Organized/ Disorganized Model of Sexual Homicide. Thesis, Victoria: Simon Fraser University, 2015. Available at: https://summit.sfu. ca/item/15907. Accessed on September 24, 2020.

MONCKTON-SMITH, Jane; ADAMS, Tony; HART, Adam; WEBB, Julia. Introducing Forensic and Criminal Investigation, Sage Publications, 2013.

PALCU, Pavel. The Need for Diversification of Forensic Tactical Rules Applicable to Crime Scene Investigation. Journal of Legal Studies, v. 19, n. 33, pp. 150-154, 2017. https://doi.org/10.1515/jles-2017-0012

PECH, Laurent, The Rule of Law as a Guiding Principle of European Union's External Action, The Hague: T.M.C. Asser Institute, CLEER, 2012. http://dx.doi. org/10.2139/ssrn.1944865

PRELIMINARY DECISION no. 113/2019 of 22 February 2019 of the High Court of Cassation and Justice of Romania. Available at: https://www.scj.ro. Accessed on April 15, 2020.

RAOULT, Sacha. How ownership of penal history was lost: An anti synthesis of modern criminal law. Journal of Law and Conflict Resolution, v. 4, n. 2, pp. 20-26, 2012. https://doi.org/10.5897/JLCR11.010

ROBERTSON, James. Forensic science, an enabler or dis-enabler for criminal investigation? Australian Journal of Forensic Sciences, v. 44, n. 1, pp. 83-91, 2012. https://doi.org/10.1080/00450618.2011.595736

ROUX, Claude; CRISPINO, Frank; RIBAUX, Olivier. From Forensics to Forensic Science. Current Issues in Criminal Justice, v. 24, n. 1, pp. 7-24, 2012. https://doi. org/10.1080/10345329.2012.12035941

SANGERO, Boaz; HALPERT, Mordechai. Why a conviction should not be based on a single piece of evidence: A proposal for reform, Jurimetrics, v. 48, n. 1, pp. 43-94, 2007. Available at: https://www.jstor.org/stable/25767388?seq=1. Accessed on May 8, 2021. 
SANTORO, Paola; LA RUSSA, Raffaele; BESI, Livia; VOLONNINO, Gianpietro; DELL'AQUILA, Massimiliano; DE MATTIES, Alessandra; MAIESE, Aniello, The forensic approach to plastic bag suffocation: Case report and review of the literature, Medico-Legal Journal, v. 87, n. 4, pp. 214-220, 2019. https://doi. org/10.1177/0025817219861277

SCHROEDER, David A.; ELINK-SCHUURMAN-LAURA, Kristin. The impact of forensic evidence on arrest and prosecution. National Institute of Justice. Boston: University of New Haven, 2017. Available at: https://www.ojp.gov/pdffiles1/ nij/grants/250721.pdf. Accessed on May 8, 2021.

SKORUPKA, Jerzy. The rule of admissibility of evidence in the criminal process of continental Europe. Revista Brasileira de Direito Processual Penal, v. 7, n. 1, pp. 93-122, 2021. https://doi.org/10.22197/rbdpp.v7i1.526

STANCU, Emilian. Tratat de Criminalistica. Bucharest: Actami Publishing House, 2001.

STOICA, Crenguta A. Cercetari privind expertizele din domeniul multimedia. Pro Lege, n. 2-3, pp. 176-189, 2019.

THEODORU, Grigore. Tratat de drept procesual penal, Third ed. Bucharest: Hamangiu Publishing House, 2013.

THOMPSON, Robert M. Firearm Identification in the Forensic Science Laboratory. Arlington, VA: National District Attorneys Association, 2010.

TOUZEAU, Nadine. Transposition of modus operandi from the real to the virtual using several signatures: Case of "the drowned of the Garonne" serial crimes in France. Forensic Science and Criminology, v. 3, n. 1, pp. 1-2, 2018. doi: 10.15761/ FSC. 1000124

UNITED NATIONS OFFICE ON DRUGS AND CRIME. Anti-human trafficking manual for criminal justice practitioners: Crime scene and physical evidence examinations in trafficking in persons investigations, Vienna, 2009. Available at: https://www. unodc.org/documents/human-trafficking/TIP_module7_Ebook.pdf. Accessed on October13, 2020.

WALTKE, Heather; LAPORTE, Gerald; WEISS, Danielle; SCHWARTING, Dawn; NGUYEN, Minh; SCOTT, Frances. Sexual Assault Cases: Exploring the Importance of Non-DNA Forensic Evidence. NIJ Journal, n. 279, pp. 1-14, 2018. Available at: https://www.ojp.gov/pdffiles1/nij/250696.pdf. Accessed on May 8, 2021.

WOODMAN, Peter A.; SPIRANOVIC, Caroline; JULIAN, Roberta; BALLANTYNE, Kaye N.; KELTY, Sally F. The impact of chemical trace evidence on justice 
outcomes: Exploring the additive value of forensic science disciplines. Forensic Science International, v. 307, pp. 110-121, 2020. https://doi.org/10.1016/j. forsciint.2019.110121

ZARAFIU, Andrei. Procedura penala. Partea generala. Partea speciala, Second ed., Bucharest: C.H. Beck, 2015.

ZARAFIU, Andrei. Implications of the new legislation on the fundamental principles of the criminal trial. Challenges of the Knowledge Society. Bucharest: "Nicolae Titulescu" University Publishing House, pp. 145-155, 2015. Available at: https:// www.proquest.com/openview/69cb9471aa57f00f829a7d6cf5465638/1?pq-origsite $=$ gscholar $\&$ cbl=2036059. Accessed on May 13, 2021.

\section{Additional information and author's declarations (scientific integrity)}

Acknowledges: I hereby would like to express my thanks to the Editor-in-Chief of the journal and two anonymous reviewers who accepted my article and decided to publish it in the Revista Brasileira de Direito Processual Penal.

Conflict of interest declaration: the author confirms that there are no conflicts of interest in conducting this research and writing this article.

Declaration of authorship: all and only researchers who comply the authorship requirements of this article are listed as authors; all coauthors are fully responsible for this work in its entirety.

Declaration of originality: the author assures that the text here published has not been previously published in any other resource and that future republication will only take place with the express indication of the reference of this original publication; she also attests that there is no third-party plagiarism or self-plagiarism. 
Dados do processo editorial

(http://www.ibraspp.com.br/revista/index.php/RBDPP/about/editorialPolicies)

- Recebido em: 06/11/2021

Equipe editorial envolvida

- Controle preliminar e verificação de plágio: 19/03/2021

- Deslocamento ao V7N2: 19/03/2021

- Editor-chefe: 1 (VGV)

- Revisores: 2

- Avaliação 1: 19/03/2021

- Avaliação 2: 24/03/2021

- Decisão editorial preliminar: 20/04/2021

- Retorno rodada de correções: 17/05/2021

- Decisão editorial final: 22/05/2021

\section{HOW TO CITE (ABNT BRAZIL):}

MAGHERESCU, Delia. Achieving Accusation by Means of Forensic Science During the Criminal Proceedings in Romania. Revista Brasileira de Direito Processual Penal, Porto Alegre, vol. 7, n. 2, p. 1287-1319, mai./ago. 2021. https://doi.org/10.22197/rbdpp.v7i2.465

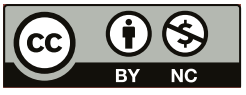

Esta obra está licenciada com uma Licença Creative Commons Atribuição-NãoComercial 4.0 Internacional. 